\title{
多成分残留分析法に関寸る二，三の考察*
}

\author{
Helmut FREHSE** \\ 宮 本 純 之***, 滝 本 善 之***訳 \\ **国際純正応用化学連合農薬委員会委員長 \\ ***住友化学工業(株)農薬事業部研究部生物科学研究所
}

\section{Some Thoughts Concerning Multiresidue Methods of Analysis*}

\author{
Helmut FreHSE** \\ Translated by Junshi Mryamoto*** and Yoshiyuki Takimoto*** \\ **Chairman, Coordinating Committee of Pesticide Chemistry, IUPAC \\ ***Research Department, Pesticides Division, Sumitomo Chemical Co., Ltd., \\ Takarazuka, Hyogo 665, Japan
}

\section{1. 多成分残留分析法の目的と特徵}

宗像教授と宮本博士は私に対し当シンポジウムの目的 のために多成分残留分析法の現況に関するいくつかの問 題点と観点につき，要約することを依頼なさいました。 この件に関しましては個人的な見解を超えてお話しでき ることはないと思われますが，喜んで話題提供を致しま しょう. 作物中の農薬の多成分残留分析に関する理論的 考察と方法のすぐれた要約は Burke と McMahon (1977) によりすでに発表されており，技法面については重要な ことをそれにつけ加えてお話しするのはむずかしいこと です.

残留分析にあたって多成分を同時に分析しようとする 試みは，本来魅力的であり，当然でもあり，むしろ得心 のゆくものであります，とくに食品の管理もしくは残留 許容量の励行にかかわっている人が多成分残留分析法に 考えを及ぼさないとは信じがたいことです．そうだとす れば，かなりの数の多成分残留分析法があるにもかかわ らず，なぜ，多くの分析者はある単一化合物のみのため の方法, 言いかえるならば多成分残留分析法以外の方法 を未だに用いているのでしょうか。

その答の一つは，当然のことながらその目的にありま

* 炤和 53 年 3 月日本農薬学会第 3 回大会シンポジウ ム“残留農薬のマルチアナリシス”における講演

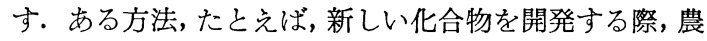
薬メーカーが考案した方法の目的は, 作物, 飼料や環境 試料をモニターしたり，もしくはすでに設定された残留 許容量(tolerance) を励行するために用いられる多成分残 留分析法の狙いとは異なります。このことは誰でも知っ ていますが，目的におけるこの違いは，両者の方法の有 用性と適応範囲にかなりの影響を与えることになるでし ょう.この点について以下に簡単に述べてみましょう.

多くの場合, “非多成分残留分析法”では，ある決め られた条件下で，ある特定の化合物の残留を測定できる だけであります．また，たとえば農薬メーカーから規制 当局に提出する必要のあるためという単純な理由で，こ の方法によれば環境下での対象化合物の挙動を評価する ために，できるだけ完全に，またかなり低い検出限界ま で当該化合物の代謝産物もしくは分解物の量をも測定す ることが多分可能でしょう．この点において，このよう な分析法は非常に“感度の高い”ものでなくてはなりま せん．たとえ同時に“選択性が高い”ことはきわめて少 ないとしても・けれども，これらの方法は“単純”で す.なぜなら，これらは管理された実験から得られる試 料の分析を目的としており，それゆえに他の化合物から の妨害, さらには未知の化合物からの妨害すら最小限に くい止められるからです.さらにこの場合無処理区の試 料をも入手でき, 多くの場合, 結果の確認の必要があり 
ませんこれらは“個々の化合物用の (single)”もしく は“化合物に特異的 (compound-specific)”な方法と呼ば れるものです。〔私としては，“化合物に合せた（compound-oriented)”方法という表現をむしろとりたい].こ の上うな方法は，かって残留データを作成した古い予備 的な方法にある程度基づいており，その後，改良もしく は簡略化されたものと言えるでしょう。

これに対し，一般の分析者は，分析試料に関する農薬 散布歴についての詳細な情報を持っていませんここのた め分析結果は, 試料中に本来含まれる成分, もしくは外 因性の他の化合物からのあらゆる種類の妨害にさらされ ているのが普通です。しかしがら，この場合には，分 析者は（規制官庁によって要請されない限り）痕跡量に まで分析を広げる必要がないことにより賞われており， また法律に含まれている範囲内でのみ分解物を測定しな ければならないだけであります。これが多成分残留分析 法の関与する領域であります.

分析法を法律に適合させる際の問題については, 10 年 以上前に Westlake と Gunther (1967) によりなされた 提案を思いだしていただきたいと思います，彼らは，よ くいろいろの組合せで用いられている 3 種のスクリーニ ング法を明確にしました。

1）分離スクリーニング：許容できる定量範囲と， 対象 1 化合物（農薬）を定め, 残留許容量（もしくは他 の定まったパラメータ）を超過した試料とそれ以下のも のとを分離する。

2）成分スクリーニング：あらかじめ検出限界を定 め, 試料中の種々の対象化合物（農薬）を検出寸る.

3）定量的スクリーニング：あらかじめ検出限界と 信頼性, 再現性とを定め, 試料中に存在するいくつかの 対象化合物（農薬）の量を定量するか，または十分に確 認する.

私の知る限り,とくにこれら,もしくは類似の基準に従 って開発された多成分残留分析法についての報文は見当 たりません・けれども，検出限界をたえず下げようとする “最近”の傾向から見て,測定に用いられる合理的な分析 法なしに検出限界は定められないという事実に対し, 繰 り返し農薬登録官の注意を喚起しなければなりません。

\section{2. 多成分残留分析法開発の現状と問題点}

残留分析を行なう人はいずれも，文献に多くの多成分 残留分析法があるという事実に直面しています（その著 者達を非難するつもりはまったくありませんが). しか し，なぜそんなに多くの方法があるのでしょうか。もし それらの内，いくつかが実際例外的に良い方法であるな
ら，なぜ新しい方法が開発されるのでしょうか。これに はいくつかの理由が考兄られます。たと充ば,

一自分自身の方法を開発するのはいいことだ。

一その研究所で手慣れた条件, (クリーンアップや $g l c$ 条件）を用いた方法を開発するのは便利である.

一言葉の障害は，外国で発表された方法を読んだり， それに気づくことの妨げになる。

一著者は知りえた分析法により，彼がとくに関心をも っているいくつかの作物一農薬の組合せ（の分析）を行な いえず，したがって，他の組合せで実験を行なった.(そ して, '多くの以前の分析法と同じく，彼のもまたその際 入手しうる作物，農薬を用いた恣意的な，もしくは偶発 的なものですらある).

もちろん, これらすべてではないにしても，これらの 内のいくつかの理由が “単一” 分析法之同様 “多成分” 分析法の双方に関連しています。

すでに存在している多成分残留分析法が，必ずしも他 の分析者に理解されたり, 受入れられたりするとは限ら ないことから，本来は良いはずの方法のより広く知られ るのが妨げられます、けれぞも，多くの分析者によって 広く, 実際的にその正しさが確かめられてはじめて, あ る分析法は認知され，また，互いの経験の交換によって 改良されることすらあります．個人的に言わせてもらう ならば, 後になって同じくらい満足すべき結果になると すれば，多くの場合，とてつもなく煩わしく，また，長 時間を要する共同研究によるよりも，上に述べたような 新しい方法を紹介し，これを検証するやり方のほうが良 いと思われます.(Frehse 1975, Anonymous 1978 参照). それゆ光すでに存在している種々の方法を比較し， 可能な限りこれを組合せて，より少ない大規模な基本的 操作法とすることを, なぜかつて誰も企てなかったのか と私は時々思います。この企ての最初は, おもに紙の上 での試みでしょう. IUPACでは, 設問形式法によって, 多成分残留分析における精製操作および検出法（または 測定法)に関する情報を照合しここれらを組合せて最適な “一般的操作法”に到達する手段とすることを,すでに 10 年前に提案しました (Frehse 1970)。だが，明らかにわ れわれは，このような試みの信奉者を見いだせませんで しだ.

*したがって，のちに McMahon と Burke が，1978 年に行なった発言に私は満足しております。彼ら は, AOAC の多成分残留分析に関する方法論の能 率の良さに言及し，その各ステップにおける化合物 の挙動に関する情報を増大させようとする FDA 内 の多くの努力を述べながら, 方法と化合物の挙動に 関するデータバンクの価值を, とりわけ強調いたし 
大部分とは言わないとしても，多くの多成分残留分析 法の大きな欠点は, 方法自身の実際の可能性いかんより もむしろ研究者とその追随者が，つぎ込んだ努力の量に よってその適用範囲が限定されていることです. 最初 は, 当該分析法が，他のどのような化合物やどの試料に 適用できるのかは，ほとんどわかっておりません，同様 に，その方法が十分に適応できない化合物や試料につい ての情報が不足しがちであります. 既存のいくつかの多 成分残留分析法の適用範囲を組合せるか，もしくは確立 された数少ない多成分残留分析法の可能性を発展させる ことは，単なる知的な試及以上のものと言うべきでしょ う. 実際そうすることは, 残留モニタリングや残留デー 夕の評価への調和のとれたアプローチを国際的へ促進し ます. また，そうすることにより，われわれのとる食品 中の残留農薬に対して，今日みられるごとき広範な懸念 に対する答えとして世界的に行なわれるべき total diet study はさらに促進されるでありましょう. 分析法がよ り広く識別されるために恐らくわれわれは, 試料, クリ ーンアップ操作や最後の測定操作を表記するための国際 的に理解できる言語のコードを作り出すようにさらに努 カすべきでしょう.

FAO とWHO により設立された CCPR（農薬残留 食品規格委員会) は, 現在 90 以上の農薬に対し, 国際 的な最大残留許容量 (Maximum residue limit, MRL) を 勧告しております. 数年前, 同委員会は, 分析法につい ての特別の作業グループを設けましたが，その目的は， CCPR が MRL を勧告している残留農薬と食品の組合 せに，国際的に受入れられる適当な残留分析法を勧告す ることです.この作業グループが勧告している方法の大 部分が，“その化合物特有の”方法であるのは興味深い ことです.私からみれば，このことは, 現存の多成分残 留分析法が，現在用いられている範囲の農薬の主要なる のに十分適合するほど幅広いものではないという明白な 証左です.また，このことは，多成分残留分析法を開発 する人々が，その方法が，通常直面すると思われる使途 を十分に考慮していないといらことを明示しています。 ヨーロッパでは，せいぜいある国にとって重要な，む しくはある国にしかあてはまらない分析法以外はありま

ました．これは，彼らがその前年（1977 年）に述べ ている見解にそったものであります。すなわち，彼 らによれば，“種々の試料に適用できる抱括的な多 成分残留分析を可能とする方法論を開発するために は, 確かな分析法を選び, これに固執し, 必要な研 究をつけ加兄, その可能性を発展させることが望ま しい. その方法の正確さの確認や研究所内および研 究所間での検証は, その後可能となる”.
せんし，しかもそれらは公定法とはなっていません. 1977 年英国で公表された数種の有機りン農薬の果実お よび荒菜における残留分析法に関する会議の報告, もし くはドイツ連邦共和国研究協会より公表されたいわゆる Becker 法（1977）は，このような例でしょう. 確かに 多くの国の公的機関で使われている他の方法もあります が，それらは必ずしも容易に外部の人が知り光るもので あるとは限りません．なお，また EEC がその加盟国の 目的のために, 分析法の勧告を, もしくは標準化すらを 計画していることをつけ加えておきましょう．米国で は, すでに述べた公知の AOAC 法や FDA 法が広く使 われています. しかし，AOAC 法は信頼すべきもので はありますが，化合物群に関する限りその範囲は非常に 狭いもののように思われます, (多分, 実際の使用例では なく, 少なくとも文献上では, McMahon と Burke 1978. 参照), そして改訂版のよく出る FDA の分析手引書を 米国以外の人々が見のがさないでいるのは容易なことで はありません．

もしこのように分析法の開発が続くなら，過去にもあ ったように，また現在でも毎年何百もの単一化合物の 分析法が報告されているように，ますます各個の多成分 残留分析法の出現に直面するのでしょう. どの方法が好 ましいかについて，一体誰が世界中の分析者に指示する ことができるでしょうか.もしそのような指示がなく， またはあっても十分説得的でなければ, 分析者が自分達 の方法を開発し続けるとしても，驚くにはあたりませ ん.ごくわずかの確実な多成分残留分析法を客観的に選 別し，勧告し，採用したのちは，できるだけ多くの分析 者によって，これをできるだけ多くの農薬・食品の組合 せに適合させるようにしょうとする目的をもった国際的 な集りをなぜ召集しないのでしょうか. 当然,すでに広 い適用範囲をもっている方法は，この目的にかなうもの です。このような方法が見つかり国際的に認知されれ ば，多分まだ個々の化合物の分析法を用いている分析者 を，しだいに多成分残留分析法の使用へ之変換させるで しょう. かくして, 逆にその方法の有効性を明らかに し，その可能性を広げることとなるでしょう．先に述べ た CCPR 特別作業グループによって毎年なされる勧告 は, 世界中の分析者からのより活発な反響をもっと必要 としておりますが，この方向にそった第一段階のものな のです.

誤解のないようお願いしたいのですが，ここで私は， “標準化法”のようなものがいいと言っているわけでは ありません.(ある分析法の良し悪しを決めるための共同 研究は, 分析法を吟味するために行なわれ，分析者を吟 
味するものではないこと, すなわち, 共同研究は熟練度 の調査ではない (Anonymous 1978)、という事実にかん がみ）私はむしろ“標準化された分析者”が望ましいと 申し上げたい.(おそらく議論の別れた場合を除き) 分析 法の厳密な規定によって，分析者の専門知識や夢を制限 しないようにする理由は多くあります，FAO/WHO の 農薬についての合同会議（FAO/WHO 1972）， CCPR (FAO/WHO 1974) とわれわれ IUPAC (1974) では, すでに表明された学問的疑惑は別にして, 標準法が必要 とされる場合に，分析者がいかにして彼の義務を果すべ きかを述べた規制を発することによって，その場合にお ける彼の義務をつけ加えるべきか否かについては，議論 の余地があることを明確に述べています. (Frehse 1975， 参照)

\section{3. 多成分残留分析法の基本的問題}

最後に，多成分残留分析法に関連した四つの基本問題 を簡単に述べてみたいと思います。

第 1 は回収率についてであります。これはもちろん， 個々の農薬の分析法にも同様に関係があります。しかし ながら，個々の分析法は，たとえば放射性物質を加えた 古い試料を同じように抽出するというような追加実験 で，はるかに実証されやすいとあえて申し上げたい。こ のようなことは，多成分残留分析法を作製する過程では ほとんどできないことであり，試料の抽出前，もしくは 抽出中に，一定量の農薬を単に添加することによって回 収率を，いいかえれば，当該分析法の有効性を調查すれ ば，“あまりに良すぎる”という誤った結果を導き出す ことになるのは明らかであります。

これに関連して，代謝産物にも言及しなければなりま せん. 残留の実質的な部分を分解物が占めている事実が 明らかなような農薬の分析法を作る際，それらの分解物 に正当な注意を払わずに親化合物のみしか考慮されてい ないことがいかに多いかは時として驚くほどです。しか しながら，どの分解物が重要であるかを考えるにあたっ て，世界中の毒性関係者および規制当局間に共通のアプ ローチが必ずしも存在しないこともまた認めなければな りますまい。これは，消費者保護と調和させるにあたっ ての末解決の分野です.

第 3 はモニタリングから得られた結果の報告について であります. 分析した X 個の試料の内， $\mathrm{Y} \%$ が検出限 界以下， Z\% が残留許容量以下， N\% があるレベルを 超えているというような誤った統計がしばしば報告され ています.これらの数字は，モニタリングに用いた分析 方法や，その測定法を検討した農薬一食品の組合せにつ
いての適切な記載がなければ,むしろ意味のないもので 于.

最後の問題点は，とくに多成分残留分析における結果 の確認の必要性に関するものです．分析法がより“完成 された”ものとなるにつれ，その方法で得られた応答シ グナルの同定や確認は，より困難となるでしょう. 予見 しうる将来にわたって，分析者が毎日の同定や定量のた めに, $g l c$ を用いることが続くでしょう.しかしながら， もしわれわれの方法が，終局的に，ますます多くの化合 物を検出できるようになった場合，日常操作を基にして 考えると，同じ保持時間を持つ半ダースもの予想化合物 を最終的にいかにして区別できるのでしょうか，もちろ ん，この問題を扱うにあたっては，分析者の経験ととも に, $t l c$ や GC/MS があるのは事実です. けれども, 試 料の分析が一日のうちにできるか否かの設問に答えるこ とこと多成分残留分析の基本的な方針ではないのでしょ うか. また，適切な同定法を開発し，多成分残留分析法 とともに，公表することを習慣づける必要があると思わ れます．分析者に最初の分析法を知らせるのみで，その 後の定性的, 定量的同定の問題を, 彼に委祆たままにし ておくという考え方にはそんなに分があるとは思われま せん.

多分，われわれは次に述べる考察を基礎として，今ま でとは異なったタイプの多成分残留分析法の開発に努め なければなりません，すなわち，

a) 化学的挙動の関連（“小規模の多成分残留分析”, 誘導化を行なう場合と行なわない場合）

b) クリーンアップと $g l c$ におけケるロマトグラフィ ックな関係

c）試料相互の関係（たとえば農薬の使用パターン）

d) 検出器の感度との関係

そして，これらの項目を互いに平行して用いなければ なりません，a）のゆえに，同様に反応する化合物は多 分，b）に従えば分けられるでしょうし，c）とd）を通 じてその可能性を除去することにより，ある化合物間を 他のものととり違える誤りは減少するでしょう。このよ うな組合せ法は，おそらく通常のやり方よりもすぐれて おり，たとえば，クロマトグラフィーでの挙動や検出器 に対する応答といった各グループ内における（化合物に よる）変更を利用できるでしょう。もちろん，このよう なやり方とて時間のかかることでしょう.けれども，ガ スクロマトグラフを使っている人には，それを試みるこ とはできると思います.

最後に，専門家の方々に，是非お答えいただきたい質 問をいたしたいと思いすす。われわれは，大規模な多成 
分残留分析法についての概念を断念すべきでしょうか. いいかえると，われわれは，すべてのものを注視すべく 準備をととのえておく必要がいつもあるのでしょうか. 警官は, 交通安全のために車のチェックをする際, 車の 分解をしません. 今週はライトを，来週はタイヤを調べ ます. 当局が農薬の適正な使用法と法律の励行を確認す るために，作物や食品をモニターするのが多成分残留分 析の明白な目的であるならば，商品として移動したり貿 易経路に入る食品について，今週は A 化合物，来週は $\mathrm{B}$ 化合物を調べるので十分ではないかと思うのです．こ れは簡単な化合物に合せた方法，もしくは小規模の多成 分残留分析法を用いれば容易に行なえます.これがやっ かいな多成分残留分析法とまったく同じ効果をもつかど うか，私にはつまびらかではありません，しかし，多分 同じだろうと思います.

多成分残留分析という重要な課題について，いくつか の考えを述べる機会を私に与えてくださいましてありが とうございました．これらは，ここにお集りの多くの方 々には，そう目新しいものではないでしょうが，私が要 約したような状況は，地球の裏側でもそう異なっていな いということを確認していただければ幸いです。ご静聴 ありがとうございました。

\section{引用 文 献}

Anonymous: Proc. Analyt. Div. Chem. Soc. 15, 223 (1978)

J. A. Burke \& B. McMahon: FDA By-Lines No. 4, January 1977, 207 (1977)

Deutsche Forschungsgemeinschaft: Verlag Chemie, Weinheim-New York, 4. Lieferung 1976, Methode S 8. (1977)

FAO/WHO: FAO Agricultural Studies No. 88, Rome; WHO techn. Rep. Ser. No. 502, Geneva. (1972)

FAO/WHO: Report of the Seventh Session of the Codex Committee on Pesticide Residues, The Hugue, Netherlands, 4-9 February 1974. ALINORM 74/24, Appendix IV. (1974)

H. Frehse: Pflanzenschutz-Nachr. Bayer 23, 196 (1974)

H. Frehse: Pure Apple. Chem. 42, 17 (1975)

IUPAC Fed. Rep. of Germany: Comptes Rendus XXVII Conference-Part B, 306 (1974)

B. McMahon \& J. A. Burke: J. Assoc. Off. Anal. Chem. 61, 640 (1978)

Anonymous: Analyst 102, 858 (1977)

W. E. Westlake \& F. A. Gunther: Residue Rev. 18, 175 (1967) 